\title{
"Employees training and its impact on learning and creativity: moderating effect of organizational climate"
}

\begin{tabular}{|c|c|}
\hline AUTHORS & $\begin{array}{l}\text { Bhawna Chahar Dttps://orcid.org/0000-0002-0473-1957 } \\
\text { R http://www.researcherid.com/rid/ABE-1034-2020 } \\
\text { Vinod Hatwal (D https://orcid.org/0000-0002-8209-8560 } \\
\text { Sona Sen (D https://orcid.org/0000-0003-2463-801X }\end{array}$ \\
\hline ARTICLE INFO & $\begin{array}{l}\text { Bhawna Chahar, Vinod Hatwal and Sona Sen (2019). Employees training and its } \\
\text { impact on learning and creativity: moderating effect of organizational climate. } \\
\text { Problems and Perspectives in Management, 17(2), 430-439. } \\
\text { doi:10.21511/ppm.17(2).2019.33 }\end{array}$ \\
\hline DOI & http://dx.doi.org/10.21511/ppm.17(2).2019.33 \\
\hline RELEASED ON & Monday, 24 June 2019 \\
\hline RECEIVED ON & Sunday, 27 January 2019 \\
\hline ACCEPTED ON & Tuesday, 12 March 2019 \\
\hline LICENSE & $\begin{array}{l}(c) \text { EY } \\
\text { This work is licensed under a Creative Commons Attribution } 4.0 \text { International } \\
\text { License }\end{array}$ \\
\hline JOURNAL & "Problems and Perspectives in Management" \\
\hline ISSN PRINT & $1727-7051$ \\
\hline ISSN ONLINE & $1810-5467$ \\
\hline PUBLISHER & LLC "Consulting Publishing Company "Business Perspectives" \\
\hline FOUNDER & LLC "Consulting Publishing Company "Business Perspectives" \\
\hline
\end{tabular}

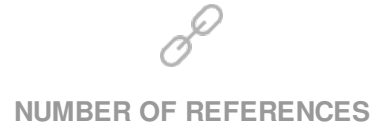

26
NUMBER OF FIGURES

2
$-=-$
$-=-$

NUMBER OF TABLES

9

(C) The author(s) 2023. This publication is an open access article. 


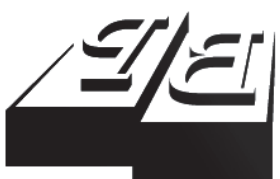

BUSINESS PERSPECTIVES

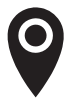

LLC "CPC "Business Perspectives" Hryhorii Skovoroda lane, 10, Sumy, 40022, Ukraine

www.businessperspectives.org

Received on: $27^{\text {th }}$ of January, 2019 Accepted on: $12^{\text {th }}$ of March, 2019

(C) Bhawna Chahar, Vinod Hatwal, Sona Sen, 2019

Bhawna Chahar, Ph.D., Associate Professor, School of Business \& Commerce, Manipal University Jaipur, India.

Vinod Hatwal, Ph.D., Lecturer, Business Studies Department, Ibri College of Technology, Oman.

Sona Sen, Research Scholar, School of Business \& Commerce, Manipal University Jaipur, India.

\section{(ㄷ)(i)}

This is an Open Access article, distributed under the terms of the Creative Commons Attribution 4.0 International license, which permits unrestricted re-use, distribution, and reproduction in any medium, provided the original work is properly cited.

\section{EMPLOYEES TRAINING} AND ITS IMPACT ON LEARNING AND CREATIVITY: MODERATING EFFECT OF ORGANIZATIONAL CLIMATE

\begin{abstract}
Economic development of any country depends on its natural resources, as well as availability of human resource. Every aspect, actions and activities in an organization involve people. Out of various resources, the human resource management has become critical resource for gaining the competitive edge. Today, most of the countries are giving attention and putting their effort to the development and training of their human resources. Training is effort initiated by an organization to foster learning among its workers. Training and development are a continuous effort designed to enhance employee learning, as well as his/her creativity, which is helpful in improving employees' competence and organizational performance. The present research work examines the moderating and mediating role of organizational climate between employees training and creativity. In a survey of 324 employees working in various SME of Dehradun area, it was found that both employee creativity and employee learning foster organizational climate. Further, the mediation effect of organizational climate on learning and creativity is different. The study shows that creativity is partially mediated, but learning has no significant effect on organizational climate. The study suggests that companies must focus on training their employees so that employees become creative and learn new practices for improving their competencies at work. The study also suggests finding the means of improving organizational climate because of its rich contribution towards improving employee creativity and learning.
\end{abstract}

Keywords

knowledge, innovation, employee skills, creativity, learning, organizational competitiveness

JEL Classification M5, I21, J24, J31

\section{INTRODUCTION}

Employee's creativity has emerged as one of the important factors to stay competitive in the fast changing global business environment. Organization that emphasize more on developing employees' creativity are found to be more competitive than others. Presently, it is observed that the researchers focused more on finding means of high work performance practices rather than finding the means to raise employees' creativity in their work. It is evident that innovation in the process improvement helps the firm in differentiating their product from competitor and helps in transforming the structure for outperforming their competitor (Tidd et al., 2005). Developing creativity a mong employees promotes the innovation in the organization and it is being extensively accepted as a key component for the entire organization to train and develop individual employees in the organization, either alone 
or in group, can create, support, examine, change, and realize the ideas that are conceived (Cirella \& Shani, 2012). Understanding artistic, as well as scientific mean of creativity, is essential for staying competitive in an evolving world and it requires organizational effort at multiple levels. To make the effective use of tools, techniques, and organizational resource, an organization needs that their employee's creative brains should function at full innovation capacity. To promote innovation and transform attitudes and behaviors of people, an organization needs to create organizational climate, develop innovation training and coaching programs for fostering creativity among people. In the present research work, we examine the role of training in generation of idea and creativity stimuli of organizational performance and productivity.

\section{LITERATURE REVIEW}

Industrial organizations whether small of big are passing through transformation stage and facing stiff competition in the market, both nationally and internationally. Achieving competitiveness in the global market has become a challenge for management and many studies reveal that creativity and innovation are the best means to achieve competitiveness across the globe. The firms' capability to develop good and services depends upon employees' creativity. Management ability to transform new idea into innovation and transform its structure makes them more competitive and determine their success. The owner and promoter of the firm, as well as management, regularly motivate, encourage, stimulate, arrange fund for innovation and development of creative idea and reward creativity and generation of idea, because these are the primary means in developing innovative products and its growth and sustainability in the market (Roper et al., 2008). The main effort of researcher is to collect relevant literature and research finding from different published and unpublished sources, review them, analyze them and explain the idea generation and how it stimulates creativity and how these ideas are associated with innovation. Apart from this, large number of managerial supportive behavior is seen as most effective in enhancing subordinates' creativity. The growing competition among the firms is continuously putting pressure on the organizations for adapting creative idea to solve the problems, promote creativeness among the employees in the organization. Finding the means to address these issues will become more and more significant concern in future.

\section{EMPLOYEES TRAINING AND ITS RELATIONSHIP WITH LEARNING AND CREATIVITY}

Human resource management practices put an emphasis on developing employee skill, competencies and making them creative and innovative. Several training activities are intended to bring creativity among employees and make them innovative. Some of the suitable methods for management training on the basis of various literature that are the subordinate performance are summarized here.

Combination of performance-based pay and subjective performance evaluation was studied by Grabner (2014) and it was found that combination matrix of performance-based pay and subjective evaluation of performance are the best for promoting creativity among employees. The author suggested that creativity incentive boosts the creativity among employees. Thus, when management decides the monetary reward policy, the creativity incentive must be included, as it will boost higher organizational commitment and ultimately higher retention. The authors like Elnaga and Imran (2013), and Garavan and Deegan (1995) suggest that effective training programs strengthen the employees' creativity, which leads to employee innovativeness in a larger context. Creativity shapes the organization with continuous growing and sustained information provides the organizations with distinctiveness helping them in differentiating from competitors whether operating nationally or internationally. Researchers like Roffe (1999), Sarri et al. (2010), Vemic (2007) emphasize that SMEs can survive if they develop the employees' innovative capacity, train them and nurture 
their innovative traits. Besides this, the success of SMEs extensively depends upon its ability to create and develop intellectual capital with creative thinking. The author suggests that appropriate sequence for the process improvement can be summarized as: the employees training will help in knowledge adoption resulting in employees innovation for gaining competitive advantage creatively. In its true sense, training promotes innovativeness among employees, brings transformation among employees and encourages their innovativeness for active involvement in the process of idea generation, idea commercialization and problem solving (De Jong \& Hartog, 2010). This type of relationship as suggested by De Jong and Hartog (2010) is also supported by Combs et al. (2006) who in their research work found that abilities, skills and knowledge of employees are improved through adapting different human resource practices like training and development practices, and employees empowerment and many more resulting in creativity and innovativeness of the employees.

\section{ORGANIZATIONAL CLIMATE AND EMPLOYEE'S CREATIVITY}

The concept of organizational climate has significant academic meaning in the field of organizational behavior. According to Likert (1967), leadership, motivation, communication, decisions, goals, and control are the important dimension on which organizational climate is based. The work on various dimensions of organizational climate was carried out by many authors and researchers. Prominent researchers like Litwin and Stringer (1968) have worked on dimensions of organizational climate and proposed seven dimensions of organizational climate. These are: responsibility, conformity, rewards, standards, warmth and support, organizational clarity, and leadership. Another researchers such as Pareek (1989), Roffe (1999) have analyzed organizational climate and proposed different dimensions like management orientation, type and nature of interpersonal relationships in the organization, nature of supervision and problem solving approach of management, conflict management policies and strategies, nature of communication, decision making techniques, level of management trust, management of rewards, risk taking, innovation and change for analyzing organizational climate.

Hunter et al. (2007) conducted a meta-analysis, exploring the moderating variables relationship between creativity and climate. Some of dimensions like support and autonomy were found to be effective predictors of creative performance; it is true for high pressure, turbulent and competitive environment. As suggested by previous literature, it was found that climate dimensions provide sizable relationships with measures of creativity. Handzic and Chaimungkalanont (2004) found that socialization among employees, whether formal or informal, has a significant positive relationship with creativity.

Communication policies and nature of communication and its impact on organizational creativity were studied by Sundgren et al. (2005). The author analyzed the role of information sharing for organizational culture and intrinsic motivation of employees. The authors proposed that information sharing among employees helps in fostering the creative work climate. It was found in the study that information sharing affects the organizational culture and organization culture mediates the relationship between information sharing and organizational creativity. The study indicates that perceived creative climate is the outcome of information sharing, culture learning, intrinsic, as well as extrinsic motivation. However, the study indicates that intrinsic motivation of employees has no significance in this relationship.

In an attempt to address such a purpose, a model of creativity development mechanism is proposed here. The various antecedents of organizational creativity have been divided into three separate variables, namely individual factors, group level factors and organizational factors. The individual level factors are personality traits of employees, domain-specific knowledge, intrinsic motivation, affect, thought fluency and imagination. At group level, factors like group cohesion, social inhibition, cognitive interference, self-construal, collectivistic value orientation, gender diversity, idea exposure, glue role and healthy inter-group conflict influence the organizational creativity and inno- 
vation. Finally, at the organizational level, the various factors like nature of the support of the supervisor, exchange relationship between the member and leader, creative personality of manager, organizational climate and culture, information sharing, training on creativity, policies of organization, motivators in job, corporate socialization and its degree and creative time pressures are important attributes influencing individual, as well as organizational creativity. In the present study, an attempt is directed to establish the relationship among the various training factors affecting employees learning and creativity and how organizational climate moderates the relationship.

\section{OBJECTIVES OF THE STUDY AND METHODOLOGY}

Although various training activities are used to enhance the employees learning and make them more creative, the success of training in encouraging innovation at the work place is being much less evaluated. This research work is intended to evaluate both the training activity and organizational creativity in terms of employees learning and increasing creativity. Present research work has been taken up with the following objectives:

a) to analyze the training and its relationship with employees learning;

b) to assess the employees training and its impact on creativity;

c) to assess the moderating effect of organizational climate on employees training, learning and creativity.

To achieve the above objectives, the data were collected from small and medium enterprises located in Dehradun. A survey instrument was chosen for collection of comprehensive data of the employees training and its outcome on employees learning and creativity. A detailed review of the literature from different sources was carried out to identify the construct for training activity, employees learning, creativity and organizational climate. A structured questionnaire was designed covering the prevailing organizational climate, the nature of training, the learning outcome and employees creativity. The researcher prepared the sampling frame for the study on the basis of enterprise size and the sector of operation. For inclusion into sampling frame, it was assured that only those firms should be included into sampling frame that have 10 or more persons engaged. The data used in this study offer information on demographic characteristics of respondents, prevailing organizational climate, nature of training, their learning outcomes and creativity among the employees. Questionnaire was used personally visiting different industries. The questionnaire for survey was distributed to a total of 500 employees working in small and medium enterprises in Dehradun. Out of them 324 responses were received (a response rate was almost $65 \%$ ). After editing, a total of 284 responses were found fit and were taken for the analysis. To test the hypothesis, factor analysis, mean, standard deviation, SEM were applied.

\section{ANALYSIS AND FINDINGS}

The model shown below (Figure 1) is the proposed model that we wish to test. The idea is testing the moderating effect of organizational climate on employee creativity and employee learning with employee training acting as the independent variable between organizational climate, employee creativity and employee learning.

Table 1 shows the demographics details of 284 sample where males were more than females and as far as age was concerned, respondents having age between 35 to 44 were the most followed by 45 to 55 years. Respondents with professional/master's degree were the most followed by bachelor's degree, and maximum respondents were employed (salaried).

Table 1. Demographics details

\begin{tabular}{l|c|c}
\hline \multicolumn{1}{c}{ Demographics details } & Frequency & \% \\
\hline \multicolumn{1}{c}{ Gender $(\boldsymbol{n}=\mathbf{2 8 4})$} \\
\hline Male & 156 & 54.9 \\
Female & 128 & 45 \\
\hline \multicolumn{1}{c}{ Age $(\boldsymbol{n}=\mathbf{2 8 4})$} \\
\hline Up to 18 years & 11 & \\
\hline From 18 to 24 years & 45 & 04 \\
\hline From 25 to 34 years & 42 & 16 \\
\hline From 35 to 44 years & 71 & 15 \\
\hline From 45 to 55 years & 56 & 25 \\
\hline 55 years and above & 27 & 20 \\
\hline
\end{tabular}




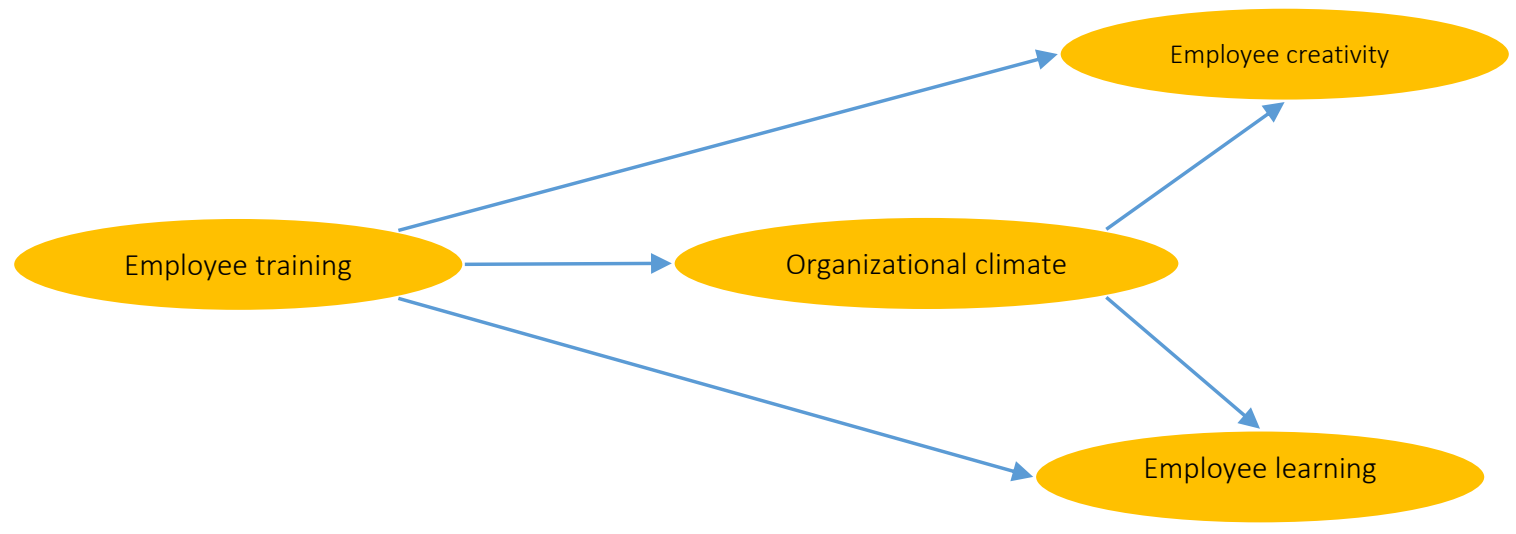

Figure 1. Proposed model

Table 1 (cont.). Demographics details

\begin{tabular}{l|c|c}
\hline \multicolumn{1}{c}{ Demographics details } & Frequency & $\%$ \\
\hline \multicolumn{1}{c}{ Academic qualification $(\boldsymbol{n}=\mathbf{2 8 4})$} & \\
\hline Non-matriculate & 03 & 01 \\
\hline Undergraduate & 20 & 07 \\
\hline Bachelor's degree & 88 & 31 \\
\hline Professional/Master's degree & 167 & 59 \\
\hline Doctorate degree & 01 & 01 \\
\hline \multicolumn{2}{c}{ Professional status ( $\boldsymbol{n = 2 8 4 )}$} \\
\hline Student & 37 & 13 \\
\hline Looking for work & 03 & 01 \\
\hline Homemaker & 20 & 07 \\
\hline Employed (salaried) & 133 & 47 \\
\hdashline Self-employed/business/ & 48 & 17 \\
freelancer/others & 34 & 12 \\
\hline Retired & 34 \\
\hline
\end{tabular}

Tabulation of data for our research was first done in MS Excel followed by conducting a factor analysis for scrutinizing the reliability of the questionnaire and hypotheses testing.

\subsection{Reliability and factor analyses}

Reliability statistics (Cronbach's $\alpha$ ) of the various constructs was calculated using SPSS software and found to be 0.837 , which is found to be sufficient enough in line with reliability suggested by Laroche et al. (1996). After assuring the reliability of the variable, the factor analysis was carried out based on principle component analysis and varimax rotation. Bartlett's test of sphericity was 0.000 and KMO value was 0.817 , this showed that questionnaire was fit and factorability assumption was met. As suggested by Kucukusta et al. (2013), Gregory and Leo (2003), only those factor loadings that were above 0.6 were retained for further anal- ysis. The variables were divided into four factors (Table 2), which account for $83 \%$ of total variance.

Structural Equation Modelling (SEM) using AMOS V25.0 and Maximum Likelihood Estimate (MLE) method were used to develop a measurement model, as AMOS is a technique that analyzes non-experimental data and also tests the relationship between observed and unobserved factors along with the intensity of relationship among these factors, it also gives the researcher the flexibility of comparing competing conceptual models and rejecting alternative models. To analyze the scale stability, CFA was used on the sample using SEM. We developed a measurement model using Confirmatory Factor Analysis (CFA) and items Q1, Q5, Q6, Q11, Q12, Q13, Q14, Q15, Q16, Q17, Q18, Q19, Q20, Q21, Q22, Q23, Q24, Q25, Q26, Q27, Q32, Q33, Q34, Q35 were removed as there factor loadings were less than 0.60 for having a better fit model.

As can be seen from Table 2, it can be concluded that our model had discriminant and convergent validity and they hold true as AVE were all above 0.50 and CR above 0.70 and CR was greater than AVE.

The next step was to test the model fit indicators. The first step was to check for CMIN/DF, which was within range of 2.787 , shown in Table 4 , indicating a good model fit.

Other goodness of fit indicators like GFI (Goodness of Fit Indicator) of $0.909>0.900$ (Table 5), NFI (Normed Fit Index) of $0.926>0.900$ (Table 6) were all in the acceptable range, indicating a good model fit. 
Table 2. AVE, CR, Cronbach's alpha and loading details

\begin{tabular}{|c|c|c|c|c|c|}
\hline Latent variable & Indicators & Loadings & AVE & Composite reliability & Cronbach's alpha \\
\hline \multirow{3}{*}{ OC } & Q2 & 0.893 & \multirow{3}{*}{0.7891} & \multirow{3}{*}{0.9049} & \multirow{3}{*}{0.8985} \\
\hline & Q3 & 0.891 & & & \\
\hline & Q4 & 0.881 & & & \\
\hline \multirow{4}{*}{ ET } & Q7 & 0.869 & \multirow{4}{*}{0.8259} & \multirow{4}{*}{0.8234} & \multirow{4}{*}{0.9499} \\
\hline & Q8 & 0.921 & & & \\
\hline & Q9 & 0.932 & & & \\
\hline & Q10 & 0.912 & & & \\
\hline \multirow{4}{*}{ EC } & Q28 & 0.772 & \multirow{4}{*}{0.7443} & \multirow{4}{*}{0.838} & \multirow{4}{*}{0.9205} \\
\hline & Q29 & 0.832 & & & \\
\hline & Q30 & 0.912 & & & \\
\hline & Q31 & 0.926 & & & \\
\hline \multirow{3}{*}{ EL } & Q36 & 0.853 & \multirow{3}{*}{0.7548} & \multirow{3}{*}{0.8266} & \multirow{3}{*}{0.9022} \\
\hline & Q38 & 0.889 & & & \\
\hline & Q39 & 0.864 & & & \\
\hline
\end{tabular}

Table 3. Factor loadings with item details and construct's alpha

\begin{tabular}{|c|c|c|c|c|}
\hline Latent variable & Indicators & Item & Loadings & Cronbach's alpha \\
\hline \multirow{3}{*}{$\begin{array}{l}\text { Fcr2: Organizational } \\
\text { Climate }(O C)\end{array}$} & Q2 & $\begin{array}{l}\text { There is strict control of people at the in the work } \\
\text { of people them }\end{array}$ & 0.893 & \multirow{3}{*}{0.8985} \\
\hline & Q3 & $\begin{array}{l}\text { The management keep tight control in the way the } \\
\text { work are done here }\end{array}$ & 0.891 & \\
\hline & Q4 & $\begin{array}{l}\text { The decision are centralized and all this are } \\
\text { checked with bass before any decision }\end{array}$ & 0.881 & \\
\hline \multirow{4}{*}{$\begin{array}{l}\text { Fcr1: Employee } \\
\text { Training (ET) }\end{array}$} & Q7 & $\begin{array}{l}\text { My orientation towards organization has changed } \\
\text { after gaining training }\end{array}$ & 0.869 & \multirow{4}{*}{0.9499} \\
\hline & Q8 & $\begin{array}{l}\text { Training program has make me to feel my } \\
\text { presence in the organization is meaningful }\end{array}$ & 0.921 & \\
\hline & Q9 & $\begin{array}{l}\text { Training program has made my job relevant to the } \\
\text { organization }\end{array}$ & 0.932 & \\
\hline & Q10 & $\begin{array}{l}\text { I am confident that my job in the organization will } \\
\text { be able to meet the business' needs }\end{array}$ & 0.912 & \\
\hline \multirow{4}{*}{$\begin{array}{l}\text { Fcr3: Employee } \\
\text { Creativity (EC) }\end{array}$} & Q28 & $\begin{array}{l}\text { Employees lookout for new idea with fellow } \\
\text { worker as part of accomplishing the task }\end{array}$ & 0.772 & \multirow{4}{*}{0.9205} \\
\hline & Q29 & $\begin{array}{l}\text { My creativity at work is always recognized and } \\
\text { honored }\end{array}$ & 0.832 & \\
\hline & Q30 & $\begin{array}{l}\text { I am always in search of performing my job in new } \\
\text { way }\end{array}$ & 0.912 & \\
\hline & Q31 & $\begin{array}{l}\text { am always in search of learning new skill that } \\
\text { help me in completing my task effectively }\end{array}$ & 0.926 & \\
\hline \multirow{3}{*}{$\begin{array}{l}\text { Fcr4: Employee } \\
\text { Learning (EL) }\end{array}$} & Q36 & $\begin{array}{l}\text { Training program has make me to feel my } \\
\text { presence in the organization is meaningful }\end{array}$ & 0.853 & \multirow{3}{*}{0.9022} \\
\hline & Q38 & $\begin{array}{l}\text { Training program has made my job relevant to the } \\
\text { organization }\end{array}$ & 0.889 & \\
\hline & Q39 & $\begin{array}{l}\text { I am confident that my job in the organization will } \\
\text { be able to meet the business' needs }\end{array}$ & 0.864 & \\
\hline
\end{tabular}

Table 4. Details of CMIN/DF

\begin{tabular}{|c|c|c|c|c|c|}
\hline Model & NPAR & CMIN & DF & $\mathbf{P}$ & CMIN/DF \\
\hline Default model & 45 & 459.927 & 165 & .000 & 2.787 \\
\hline Saturated model & 210 & 0.000 & - & - & - \\
\hline Independence model & 20 & 6222.722 & 190 & .000 & 32.751 \\
\hline
\end{tabular}

Table 5. Details of GFI and other indicators

\begin{tabular}{|c|c|c|c|c|}
\hline Model & RMR & GFI & AGFI & PGFI \\
\hline Default model & 0.117 & 0.909 & 0.859 & 0.699 \\
\hline Saturated model & 0.000 & 1.000 & - & - \\
\hline Independence model & 0.327 & 0.287 & 0.212 & 0.260 \\
\hline
\end{tabular}




\subsubsection{Baseline comparisons}

Table 6. Details of NFI and other indicators

\begin{tabular}{l|c|c:c:c|c}
\hline Model & $\begin{array}{c}\text { NFI } \\
\text { Delta } \\
\mathbf{1}\end{array}$ & $\begin{array}{c}\text { RFI } \\
\text { Rho }\end{array}$ & $\begin{array}{c}\text { IFI } \\
\text { Delta }\end{array}$ & $\begin{array}{c}\text { TLI } \\
\text { Rho }\end{array}$ & CFI \\
$\mathbf{2}$ & $\mathbf{2}$ & \\
\hline Default model & 0.926 & 0.915 & 0.951 & 0.944 & 0.951 \\
Saturated model & 1.000 & - & 1.000 & - & 1.000 \\
$\begin{array}{l}\text { Independence } \\
\text { model }\end{array}$ & 0.000 & 0.000 & 0.000 & 0.000 & 0.000 \\
\hline
\end{tabular}

After goodness of fit indicator, badness of fit indicator was checked and root mean squared error of approximation (RMSEA) was also under acceptable range of $0.049>0.50$.

\subsubsection{RMSEA}

Table 7. Details of RMSEA and other indicators

\begin{tabular}{|c|c|c|c|c|}
\hline Model & RMSEA & LO 90 & HI 90 & PCLOSE \\
\hline Default model & 0.049 & 0.062 & 0.077 & 0.000 \\
\hline Independence model & 0.292 & 0.286 & 0.298 & 0.000 \\
\hline
\end{tabular}

All this indicated that our model was a perfect fit as per measurement model and then Structural Equation Modelling (SEM) was done converting the measurement model into structural model (see Figure 2).

Figure 2 shows the structural model with path coefficients and $R^{2}$ details and Table 8 shows the detailed value. It is now time to examine them, the first path coefficient between ET and OC is $54 \%$, which means a strong relationship between the two, the second between ET and EC is 31\%, which is also strong, followed by ET and EL at $30 \%$. Then, OC and EL was at $24 \%$ and the weakest was between OC and EC at 21.1\%.

Table 8. Details of path coefficients

\begin{tabular}{c|c}
\hline Relationship & Estimate \\
\hline OC $\leftarrow$ ET & .540 \\
$E C \leftarrow E T$ & .310 \\
$E L \leftarrow E T$ & .306 \\
$E L \leftarrow$ OC & .248 \\
EC $\leftarrow$ OC & .211 \\
\hline
\end{tabular}

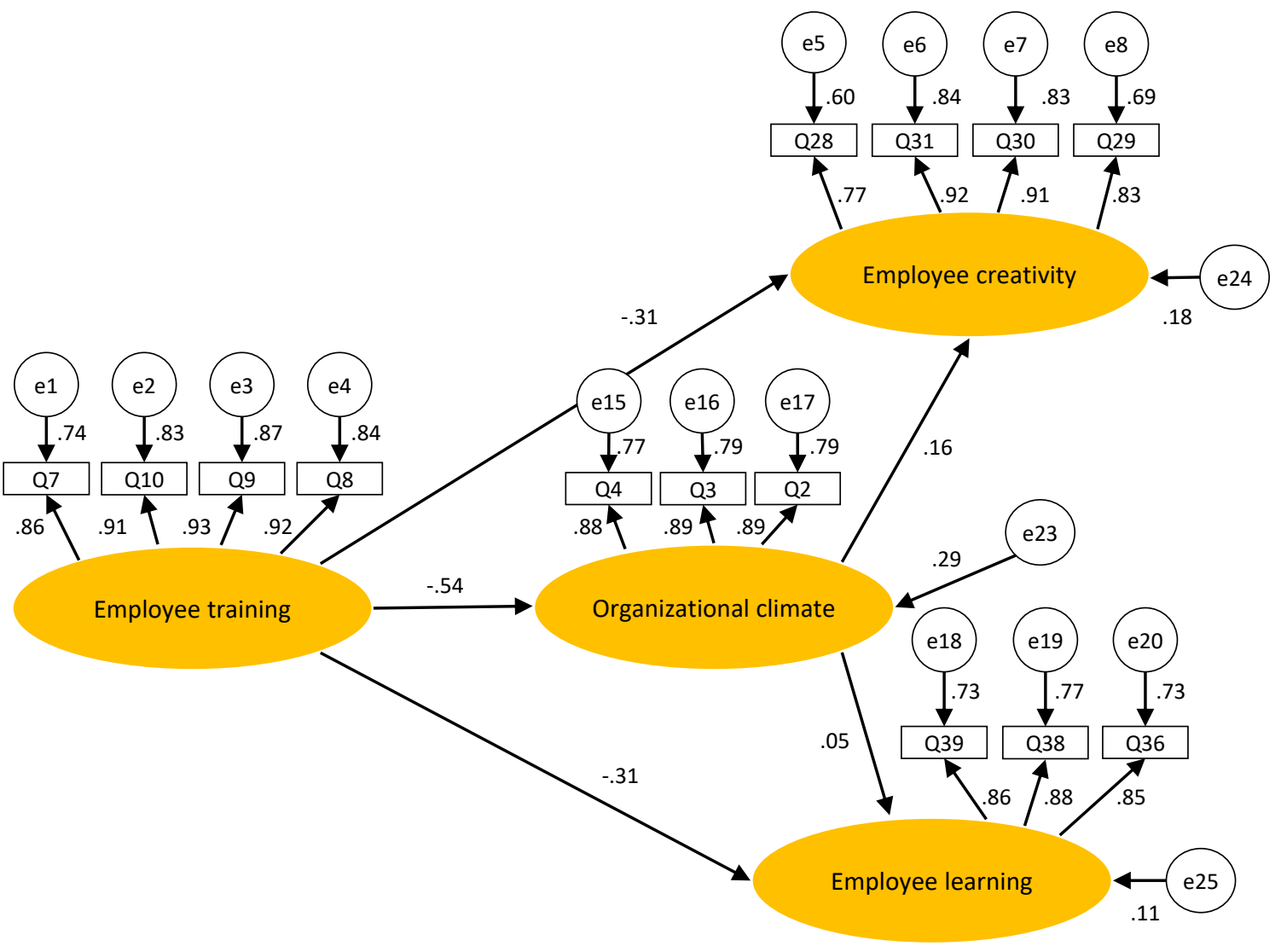

Figure 2. Structural model 
Table 9 is the most important table summarizing the mediation effect and as can be seen Table 9, there is no mediation between ET and EL, so it can be concluded that organizational climate has no effect on employee learning, but it does have a partial mediation effect between employee training and organizational climate.

Table 9. Details of mediation

\begin{tabular}{c:c:c:c}
\hline Hypothesis & $\begin{array}{c}\text { Direct effect } \\
(\boldsymbol{x} \rightarrow \boldsymbol{y})\end{array}$ & $\begin{array}{c}\text { Indirect } \\
\text { effect }(\boldsymbol{X} \cdot \boldsymbol{Y})\end{array}$ & Result \\
\hline $\mathrm{ET} \rightarrow \mathrm{OC} \rightarrow \mathrm{EC}$ & $0.31^{* * *}$ & $0.25^{*}$ & $\begin{array}{c}\text { Partial } \\
\text { mediation }\end{array}$ \\
\hdashline $\mathrm{ET} \rightarrow \mathrm{OC} \rightarrow \mathrm{EL}$ & $0.31^{* * *}$ & $0.08(\mathrm{~ns})$ & No mediation \\
\hline
\end{tabular}

Note: ${ }^{* *}-p<0.001 ;{ }^{*}-p<0.05$; ns - "not significant".

\section{DISCUSSION}

In past few years, so many researches were undertaken and their findings have reported the relationship between employees training and their learning. The continuous increasing pressures on business organizations for adapting new technology and meeting the global challenges call for employees resourcefulness and creativity. The finding of our research found to be in confirmation of the previous researchers like Hutchings, Zhu, Cooper, Zhang, and Shao (2009), positive effect of training and development on employees technical and interpersonal skill and abilities enhance their learning and abilities, motivate them to work in team, increase their job confidence and enhance the work motivation. The finding of our study is also supported by Noe et al. (2010) who confirm that organizations spend an enormous amount of money and time on training in order to help employee's in learning the job-related competencies. Further the focus has shifted in the last decade and much importance was given to developing employees creativity, because it leads to innovation. As a result, several research studies have confirmed that employees creativity has been able to beat their basic performance expectation (e.g., Jung \& Avolio, 2000). The finding of study by Yevugah and Caesar (2018) confirms a strong relationship between job training fit and employee creativity. Findings of the present study confirm the previous finding and contribute a lot in the area of employee creativity.

The proposed hypothesis of mediating role of organizational climate was statistically supported and confirms the previous research conducted by Ekvall and Ryhammar (1998). In this study, the authors found climate as a lever of creativity and learning of employees. They concluded that employee's creativity is mediated through organizational climate. The outcome of present study is in line with the outcome of Jung et al. (2003), showing that organizational climate mediates the employee creativity, but not the employee learning.

\section{CONCLUSION}

This study found that both employee creativity and employee learning foster organizational climate. Further, the effects of employee creativity mediated by organizational climate and employee learning also mediated by organizational climate were dissimilar and the analysis showed that creativity is partially mediated, but learning has no effect on organizational climate that makes sense as training will impact the learning and it has nothing to do with organizational climate, as employees are mature enough to understand the fact that companies invest a lot in employees and they need to justify their salaries whatever condition they are in, but employee creativity is a different factor and needs to be nurtured to see better results and will be affected by organizational climate. As creativity comes naturally to some and to others through effective learning, it can be inculcated, since our results showed that there is a mediation effect of organizational culture on creativity apart from training. The results however can be different if different demographics are moderated and the same model if tested in other area will have a different result. It is suggested that companies must focus on training so that employees become creative and learn new best practices to become efficient in their work, which in turn leads to organization's output and one must not forget the contribution of organizational climate to employee creativity and learning. 


\section{REFERENCES}

1. Cirella, S., Guerci, M., \& Shani, A. R. (2012). A process model of collaborative management research: The study of collective creativity in the luxury industry. Systemic Practice and Action Research, 25(3), 281-300. https:// doi.org/10.1007/s11213-0119220-x

2. Combs, J., Liu, Y., Hall, A., \& Ketchen, D. (2006). How much do high-performance work practices matter? A meta-analysis of their effects on organizational performance. Personnel Psychology, 59(3), 501-528. https://doi.org/10.1111/j.17446570.2006.00045.x

3. De Jong, J., \& Hartog, D. D. (2010). Measuring innovative work behavior. Creativity and Innovation Management, 19(1), 23-36. https://doi.org/10.1111/ j.1467-8691.2010.00547.x

4. Ekvall, G., \& Ryhammar, L. (1998). Leadership style, social climate and organizational outcomes: A study of a Swedish University College. Creativity and Innovation Management, 7(3), 126-130. https://doi. org/10.1111/1467-8691.00100

5. Elnaga, A., \& Imran, A. (2013). The Effect of Training on Employee Performance. European Journal of Business and Management, 5(4), 137-147. Retrieved from https://www.iiste.org/Journals/index.php/EJBM/article/ view/4475/4543

6. Garavan, T. N., \& Deegan, J. (1995). Discontinuous change in organizations. Using training and development interventions to develop creativity. Industrial and Commercial Training, 27(11), 18-25. https://doi. org/10.1108/00197859510147607

7. Grabner, I. (2014). Incentive system design in creativitydependent firms. The Accounting Review, 89(5), 1729-1750. https:// doi.org/10.2308/accr-50756

8. Gregory, G. D., \& Leo, M. D. (2003). Repeated Behavior and Environmental Psychology: The role of Personal Involvement and Habit Formation in Explaining Water Consumption 1. Journal of Applied Social Psychology, 33(6), 1261-1296. https://doi. org/10.1111/j.1559-1816.2003. tb01949.x

9. Handzic, M., \& Chaimungkalanont, M. (2004). Enhancing organizational creativity through socialization. The Electronic Journal of Knowledge Management, 2(1), 57-64. Retrieved from https://www.researchgate. net/publication/254427961_Enhancing_Organisational_Creativity_Through_Socialisation

10. Hunter, S. T., Bedell, K. E., \& Mumford, M. D. (2007). Climate for creativity: A quantitative review. Creativity Research Journal, 19(1), 69-90. https://doi. org/10.1080/10400410709336883

11. Hutchings, K., Zhu, C. J., Cooper, B. K., Zhang, Y., \& Shao, S. (2009). Perceptions of the effectiveness of training and development of 'grey-collar' workers in the People's Republic of China. Human Resource Development International, 12(3), 279-296. https://doi. org/10.1080/13678860902982033

12. Jung, D. I., Chow, C., \& Wu, A. (2003). The role of transformational leadership in enhancing organizational innovation: Hypotheses and some preliminary findings. The Leadership Quarterly, 14(4-5), 525-544. https://doi.org/10.1016/S10489843(03)00050-X

13. Jung, D., \& Avolio, B. (2000). Opening the black box: An experimental investigation of the mediating effects of trust and value congruence on transformational and transactional leadership. Journal of Organizational Behavior, 21(8), 949-964. https://doi.org/10.1002/10991379(200012)21:8<949::AIDJOB64>3.0.CO;2-F

14. Kucukusta, D., Mak, A., \& Chan, X. (2013). Corporate Social Responsibility Practices in Four and Five Star Hotels: Perspectives from Hong Kong Visitors. International Journal of Hospitality Management, 34, 19-30. Retrieved from http://hdl. handle.net/10397/12724

15. Laroche, M., Toffoli, R., Kim, C., \& Muller, T. E. (1996). The influence of culture on proenvironmental knowledge, attitudes, and behavior: A Canadian perspective. Advances in Consumer Research, 23, 196-202. Retrieved from http:// acrwebsite.org/volumes/7942/ volumes/v23/NA-23

16. Likert, R. (1967). The human organization: its management and values. New York: McGraw-Hill.

17. Litwin, G. H., \& Stringer, R. A. (1968). Motivation and organizational climate. Boston: Division of Research, Harvard University.

18. Noe, E., Hollenbeck, J. R., Gerhart, B., \& Wright, P. M. (2010). Human Resource Management: Gaining Competitive Advantage (7th ed.). Boston: McGraw-Hill.

19. Pareek, U. (1989). Motivational analysis of organizations-climate (MAO-C). In J. W. Pfeiffer (Ed.), The 1989 annual: Developing human resources (pp. 161-171). San Diego, CA: University Associates.

20. Roffe, I. (1999). Innovation and creativity in Organizations: a review of the implications for training and development. Journal of European Industrial Training, 23(4-5), 224-241. https://doi. org/10.1108/03090599910272103

21. Roper, S., Du, J., \& Love, J. H. (2008). Modelling the innovation value chain. Research Policy, 37(6-7), 961-977. https://doi. org/10.1016/j.respol.2008.04.005

22. Sarri, K. K., Bakouros, I. L., \& Petridou, E. (2010). Entrepreneur training for creativity and innovation. Journal of European Industrial Training, 34(3), 270-288. https://doi. org/10.1108/03090591011031755 
23. Sundgren, M., Dimenäs, E., Gustafsson, J. E., \& Selart, M. (2005). Drivers of organizational creativity: a path model of creative climate in pharmaceutical R \& D. $R$ \& D Management, 35(4), 359-374. https://doi.org/10.1111/ j.1467-9310.2005.00395.x

24. Tidd, J., Bessant, J., \& Pavitt, K. (2005). Managing Innovation: Integrating Technological, Market and Organizational Change (3rd ed.). John Wiley and Sons Ltd. Retrieved from https://www. amazon.com/Managing-Innovation-Integrating-TechnologicalOrganizational/dp/0470093269

25. Vemic, J. (2007). Employee Training And Development And The Learning Organization. Journal of Economics and Organization, 4(2), 209-216. Retrieved from http://facta.junis.ni.ac.rs/eao/ eao200702/eao200702-13.pdf
26. Yevugah, D., \& Caesar, L. (2018). Examining the Effects of Job Training-Fit on Employee Creativity and Performance. The International Journal of Business \& Management, 6(4), 15-22. Retrieved from https:// www.academia.edu/38397568/ Examining_the_Effects_of_Job_ Training-Fit_on_Employee_ Creativity_and_Performance. pdf 